\title{
Effect of Soil Infiltration Capacity, Soil Texture and Rainfall on Soil Erosion Occurring under Different Land Use Land Cover (LULC) in Miandam Valley Swat, Pakistan
}

\author{
Nowsher Yousaf ${ }^{*}$, Bushra Khan ${ }^{1}$, Dennis Flanagan ${ }^{2}$ and Ishaq Ahmad Mian ${ }^{3}$ \\ ${ }^{1}$ Department of Environmental Sciences University of Peshawar, 25120, Pakistan; ${ }^{2}$ USDA-Agricultural Research Service, \\ National Soil Erosion Research Laboratory USDA-ARS Purdue University, West Lafayette, Indiana 47906, USA; ${ }^{3}$ Department \\ of Soil and Environmental Sciences, the University of Agriculture, Peshawar, 25120, Pakistan.
}

\begin{abstract}
Soil erosion is one of the major threats to the soil of Miandam valley, Swat Pakistan. The soil of the valley is one of the most fragile and vulnerable to erosion. The main objective of this research was to investigate the effect of soil infiltration capacity, soil texture and rainfall on soil erosion occurring under various land use land cover (LULC) in the study area. Soil erosion was monitored through erosion pipes over the period from 2016 to 2017 in three different vegetation density zones i.e. dense forest, moderate forest and agriculture land. Results showed that the amount of rainfall, soil texture and soil infiltration capacity were important factors affecting soil erosion. The sandy clay loam soils of dense forest lands had a relatively small intensity of erosion $\left(2.1 \mathrm{~mm} \cdot \mathrm{yr}^{-1}\right)$ due to mean annual rainfall of $31.46 \mathrm{~mm} \cdot \mathrm{yr}^{-1}$ with high soil infiltration capacity value of $19.8 \mathrm{~cm} / \mathrm{h}$ while the sandy clay loam soils of moderate forest lands having soil infiltration capacity value of $16.4 \mathrm{~cm} / \mathrm{h}$ have mean annual erosion of $2.9 \mathrm{~mm} . \mathrm{yr}^{-1}$ due to mean annual rainfall of 31.46 $\mathrm{mm} \cdot \mathrm{yr}^{-1}$. The highest soil erosion $\left(4.6 \mathrm{~mm} \cdot \mathrm{yr}^{-1}\right)$ occurs at sandy loam soil of agriculture lands having lowest soil infiltration capacity value of $11.4 \mathrm{~cm} / \mathrm{hwith}$ mean annual rainfall of $31.46 \mathrm{~mm} . \mathrm{yr}^{-1}$. As soil erosion is greatly impacted by vegetation cover therefore renewed hydrological situation encouraged by vegetation cover and insights into soil erosion processes can highlight useful design for new strategies on management of erosion and restoration of ecosystem.

Received: July 13, 2020; Accepted: October 30,2020; Published: December 19, 2020

*Correspondence: Nowsher Yousaf, Department of Environmental Sciences, University of Peshawar, Peshawar, 25120, Pakistan; Email: nyousaf@ uop.edu.pk

Citation: Yousaf, N., B. Khan, D. Flanagan and I.A. Mian. 2021. Effect of soil infiltration capacity, soil texture and rainfall on soil erosion occurring under different land use land cover (LULC) in Miandam Valley Swat, Pakistan. Journal of Engineering and Applied Sciences, 39(2): $135-142$.

DOI: http://dx.doi.org/10.17582/journal.jeas/39.2.135.142

Keywords: Soil erodibility, Rainfall, Erosion pipes, Miandam valley, Swat, Pakistan
\end{abstract}

\section{Introduction}

Soil erosion is amongst the critical environmental Problems which the world is facing nowadays (Schonbrodt-Stitt et al., 2013; Le Roux et al., 2007, 2008; Wei etal.,2007; Meadows,2003; Ma etal.,2014). Anthropogenic activities such as mining, continuous agriculture activities and over grazing accelerate the natural process of soil erosion (Lieskovsky' and Kenderessy, 2012; Gimenez-Morera et al., 2010; Ziadat and Taimeh, 2013; Mandal and Sharda, 2013; Leh et al., 2013; Zhao et al., 2013).

The problem of soil erosion increases with increase in the anthropogenic activities such as construction, population expansion, agriculture production and 
urbanization (Leh et al., 2011; Ding et al., 2015; Wu and Xie, 2011). Poor land management is one of the factor that cause soil erosion thus increase the runoff and damages the soil (Nadeu et al., 2012; Liu, 2016; Niu et al., 2015; Montgomery et al., 2014).

In unprotected sloppy areas, soil loosening, transportation and deposition are the three actions which characterizes soil erosion. The top soil layer which is rich in nutrients and organics is relocated due to these processes. It relocates elsewhere on-site and builds up overtime or it accumulates in drainage channels (Shi et al., 2012). Rain water breaks up the soil, dislodges it and washes it away as runoff. Soil erosion process varies for various LULC types (Sun et al., 2014; Liu, 2016). The LULC having inadequate vegetation cover and sloped topography are more susceptible to soil erosion due to long duration of rainfall (Vrieling et al., 2009; Marques et al., 2007; Rohrmann et al., 2013; Zhao et al., 2014; Lee and Lee, 2006). The amount of soil erosion is decreased due to crops and grasses on the surface which support the structure of the soils. The soil is more susceptible to erosion in the areas having less natural flora (Pimentel and Burgess, 2013). Soil type, LULC type, topography, precipitation and land management are the main factors responsible for soil erosion (Panagos et al., 2015).

Infiltration which is an important component in the hydrological cycle is the process of water movement from ground surface into the soil (Haghiabi et al., 2011). For predicting surface run-off infiltration is one of the important soil parameter (Oyonarte et al., 2002; Idike, 2002). The surface of the soil having less infiltration has greater chances to become saturated during rainfall events which enhances the potential of erosion by decreasing soil strength and increasing particles detachment. In the areas with steep slopes and saturated soil conditions, the movement of surface materials lying above the compacted layer are common. An increase in saturation or decrease in infiltration may also cause nutrients deficiencies (Schwab et al., 1995). Once the minor undulations in the surface have been filled, water will flow overland as surface runoff with excess of infiltration capacity. Runoff is more frequent on degraded soils depending on rainfall intensity and topography (Sreejani et al., 2017).

Slope steepness, LULC and rainfall are among those factors which influence soil erosion. One of the most important factors that influence soil erosion rates is rainfall (Serrano-Muela et al., 2013; Cerda, 2002). Soil erosion is also influenced by the LULC type. The cultivation practices under agricultural land use increases soil erosion as compared to land covered with forest (Cerdà, 2000). As the soil infiltration capacity is enhanced by the presence of vegetation cover which reduce the soil erosion rates thus soil loss is accelerated with cultivation of land without providing the protection measures (Cerdà, 1999).

This study aims at achieving the objective of studying the effect of rainfall, soil infiltration capacity and soil texture on the soil erosion occurring under various land uses in Miandam valley Swat Pakistan.

\section{Materials and Methods}

\section{Soil erosion measurement through erosion pipes}

Erosion from ground surface was monitored through erosion pipes. The erosion pipes were inserted carefully into the soil surface. To minimize the soil disturbance, the pipes were inserted through uniform impact of hammering. As the ants disturbs the soil, therefore the site selection was made accordingly in order to minimize the disturbance. During the monitoring period, about 9 pipes were found missing from different sites as a result of different anthropogenic activities which were replaced immediately. $1 \mathrm{~mm}$ precision hand tape was used to carry out the measurement. As measuring erosion less than $1 \mathrm{~mm}$ is difficult, therefore this precision is suitable. The exposed end of the pipes above ground surface were enamel painted for identification of pipes. The rapid identification of erosion or deposition is made easier through this technique. Three monitoring sites were established for different LULC types i.e. dense forested area, moderate forested area and agriculture lands. The slope length varied from $28 \mathrm{~m}$ to $38 \mathrm{~m}$ which represents typical Miandam valley's land topography. After each rainfall event, the exposed length of the pipes above soil surface were measured by using $1 \mathrm{~mm}$ precision measuring tape.

A total number of 72 pipes (12 inch galvanized pipes) were taken (Table 1). Two plots with 12 pipes each were selected in three different land uses. 24 pipes were driven into three different land uses i.e. dense forested (Figure 1), moderate forested (Figure 2) and agricultural land (Figure 3 ) each with a hammer. 
After each rainfall event, the three inches pipe left exposed was measured in order to estimate soil loss or deposition by measuring the difference in soil level before and after each rainfall event. For making the exposed 3 inches of the pipes visible, it was painted with a bright color (Yellow). One end of the pipe was beveled before placing a pipe into the ground to make the hammering easier. To make measurement easier, pipes were numbered. Depending on the LULC types, the pattern and number of erosion pipes vary from one location to other. 3 to 4 pipes were installed vertically within few inches of distance from each other. In order to make monitoring easier, installment of pipes was done at nearby locations at six stations under the three different LULC types. The height of the pipes (Day "0" data) was measured just after installments of the pipes. It was then measured periodically to the nearest millimeters. As the purpose of the study specifies the measurement frequency, so for this study the measurement of erosion pipes was done after every rain event. Erosion pipes records soil erosion as well as deposition.

Table 1: Characteristics of erosion sites.

\begin{tabular}{|c|c|c|c|c|}
\hline Site & Land use & $\begin{array}{l}\text { Plot size } \\
(\mathrm{m} \times \mathrm{m})\end{array}$ & $\begin{array}{l}\text { Slope } \\
\text { length (m) }\end{array}$ & $\begin{array}{l}\text { No. of ero- } \\
\text { sion pipes }\end{array}$ \\
\hline 1 an & $\mathrm{De}$ & $12 \times 12$ & 28 & $12+12=24$ \\
\hline 3 and & Moderate forest & $12 \times 12$ & 32 & $12+12=24$ \\
\hline 5 and 6 & 5 Agriculture land & $12 \times 12$ & 38 & $12+12=24$ \\
\hline
\end{tabular}

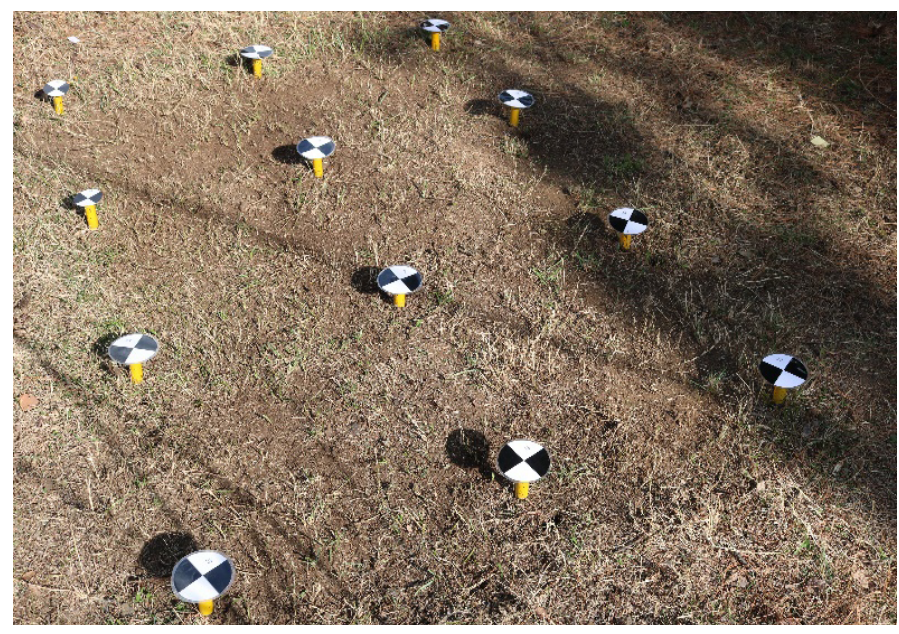

Figure 1: Erosion pipes installation in dense forested area.

\section{Soil infiltration capacity}

Soil samples were collected in the soil sample tubes. Soil sample tube is a cylindrical tube with an average diameter of $7.5 \mathrm{~cm}$ and an average height of $2.5 \mathrm{~cm}$ open at both ends. In each density zone, five points were selected for sampling. In about one square foot area, floor (litter, humus, grass, etc.) was removed from each point. The soil sampler was placed over each point with sharp edge pointed ward. It was driven into the soil with the help of a hammer. The sample tube along with a core of soil was dug out by removing the soil around the sample tube. Cotton cloth was used to cover soil sample and fastened with rubber bands on both sides. Sample tube was enveloped in a polythene bag. The entire fifteen samples (five from each zone) were taken in the same manner and brought to the laboratory.

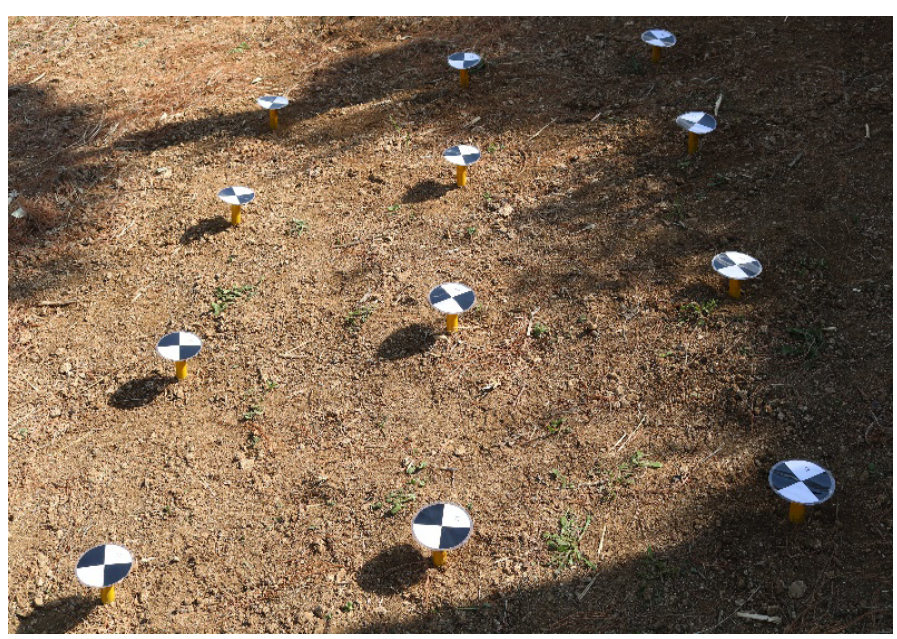

Figure 2: Erosion pipes installation in moderate forested area.

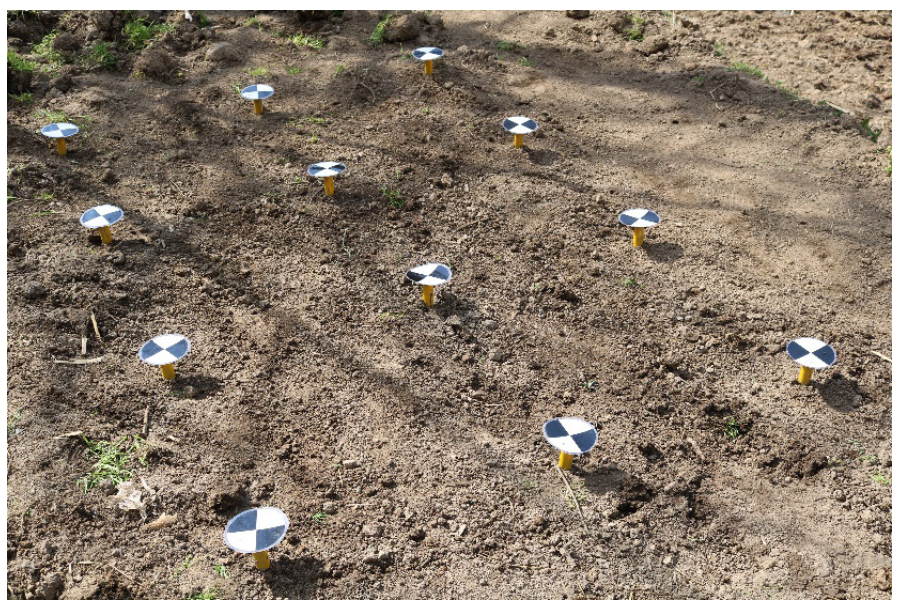

Figure 3: Erosion pipes installation in agricultural land.

The sample tubes were soaked in the sink for saturation overnight keeping the level of water just below the upper edge of the sample tube. The cloth on both sides of the sample tube was removed. Sampler was set up on perimeter after replacing cloth with wire mesh on lower side. The discharge was measured for 20 minutes after the flow of water through the soil core becomes constant. An average of four measurements gave the infiltration rate as the discharge was measured after every five minutes separately. Soil infiltration capacity was determined by using the following equation;

$$
K=Q / A(H S / H S+H W)
$$


Where;

$\mathrm{K}=$ Permeability $(\mathrm{cm} / \mathrm{hr}) ; \mathrm{Q}=$ Average infiltration rate as discharge in the system (cc/min); $A=$ Cross sectional area of the sample $\left(\mathrm{cm}^{2}\right) ; \mathrm{HS}=$ Height of the soil column $(\mathrm{cm}) ; \mathrm{HW}=$ Height of the water from the top of soil to free water surface (Hussain, 2005).

\section{Soil texture}

$150 \mathrm{ml}$ distilled water was added to dispersion cup containing $20 \mathrm{~g}$ of air dried soil sample. In order to make the volume of the dispersion cup up to the mark, $10 \mathrm{ml}$ of $1 \mathrm{~N}\left(\mathrm{Na}_{2} \mathrm{Co}_{3}\right)$ was added. After the addition, it was stirred for 10 mints to breakdown the aggregates. The contents of the dispersion cup were transferred to $1 \mathrm{ml}$ dispersion cup. After shaking the suspension, it was placed on the table for a while and the time was noted. The $40 \mathrm{sec}$ reading was taken after inserting the hydrometer into the suspension which gives the percent silt and clay content of the soil. The percent clay contents were taken from the second reading which was noted after 2 hours. Temperature was also recorded while taking both the readings. By using the soil textural triangle, soil texture was determined by calculating the percent sand, silt and clay (Koehler $e t$ al., 1984).

\section{Statistical analysis}

Group means measured in the three different landscape types for soil erosion were compared using one-way ANOVA. Firstly, the three types were tested independently to reveal any difference as a result of succession stage. For multiple comparisons (among LULC types), Tukey's honest significance test was applied when the F test was significant. SPSS version 23.0 (SPSS, Inc., Chicago, Illinois) statistical software was used for data analyses including the correlation analysis. Significance level was set at $\mathrm{P}<0.05$. There was no need for any further data transformation as all our data passed the normality test.

\section{Results and Discussion}

From the data analysis it was evident that there was a significant effect of soil texture, soil infiltration capacity and rainfall amount on the soil erosion rates occurring under different LULC types. Therefore, the discussion will mainly focus on the effect of each factor separately on soil erosion rates.

\section{Soil erosion rates under different land uses}

Measured data indicated that the highest soil erosion rate was recorded from agriculture land which varied from 2.1 to $8.7 \mathrm{~mm} . \mathrm{yr}^{-1}$ followed by moderate forest from 1.3 to $6.1 \mathrm{~mm} \cdot \mathrm{yr}^{-1}$ (Table 2). The lowest erosion rates were recorded from dense forest zone which varied from 1.1 to $4.7 \mathrm{~mm} . \mathrm{yr}^{-1}$. The difference in the erosion rates indicates that soil erosion is strongly influenced by LULC type. In order to determine the soil erosion, vegetation cover plays an important role than the slope steepness (Kukal et al., 1991).

Table 2: Mean annual soil erosion occurring under various land uses in Miandam valley.

\begin{tabular}{llll}
\hline $\begin{array}{l}\text { Land use/ } \\
\text { Land cover }\end{array}$ & $\begin{array}{l}\text { Mean annual } \\
\text { erosion }(\mathbf{m m} .\end{array}$ & \multicolumn{2}{c}{ Statistical analysis } \\
\cline { 1 - 4 } $\left.\mathbf{y r}^{-1}\right)$ & $\begin{array}{l}\text { Over all } \\
\text { P-Value }\end{array}$ & $\begin{array}{l}\text { Status com- } \\
\text { parison }\end{array}$ \\
\hline Dense forest & 2.1 & $<0.001$ & DFMFAL \\
Moderate forest & 2.9 & $<0.001$ & MFDFAL \\
Agriculture land & 4.6 & $<0.001$ & ALDFMF \\
\hline
\end{tabular}

DF: Dense Forest; MF: Moderate Forest; AL: Agricultural Land; Abbreviations in status comparison column indicate level of significant differences among different LULC types ( $p<0.05)$.

The accuracy in the measurement method is very important due to relatively small amount of erosion occurring under dense and moderate forest zones. The sources of errors and variation in the measurement of erosion are mentioned in the review provided by Boix-Fayos et al. (2006). The issues which are related mainly focus on the aspects of; representing the natural conditions, Spatial and temporal scales and natural conditions disturbance. Different sources of errors may occur. The soil surface may become loose to some extent due to insertion of erosion pipes due to which misleading or excessive erosion rates might be produced. Ant activities can also disturb the erosion pipes so as human's disturbance. Thin iron pipes were used to minimize the chances of error while taking the measurement.

For conserving soil, vegetation plays an important role due to its reducing role in erosive impact of precipitation. According to many studies, increasing vegetation cover decreases the soil erosion rates e.g., (Mohammad and Adam, 2010; Vásquez-Méndez et al., 2010). In addition, the soil's resistance to erosion increases due to soil cohesion by plant roots (De Baets et al., 2008). The soil loss is further reduced by the healthy growth of trees and shrubs (Zheng, 2006). The presence of vegetation covers and leaf litter has a greater influence on the rates of infiltration capacity, soil erosion and water runoff (Singh et al., 2001). 
Effect of soil infltration capacity on soil erosion rates

The decreased amount of soil infiltration capacity due to less vegetation cover is evident from (Figure 4). The soil of dense forest areas (high density) is having maximum mean soil infiltration capacity $(19.8 \mathrm{~cm} / \mathrm{h})$, therefore it is less susceptible to soil erosion having mean soil erosion rate of $2.1 \mathrm{~mm} \cdot \mathrm{yr}^{-1}$ followed by moderate forest (medium density) which is $16.4 \mathrm{~cm} / \mathrm{h}$ and having mean soil erosion rate of $2.9 \mathrm{~mm} \mathrm{yr}^{-1}$.The lowest mean soil infiltration capacity value is of the soil of agricultural areas (low density) which is 11.4 $\mathrm{cm} / \mathrm{h}$. Therefore the soil of agriculture land is more susceptible to soil erosion with mean soil erosion rate of $4.6 \mathrm{~mm} \cdot \mathrm{yr}^{-1}$.

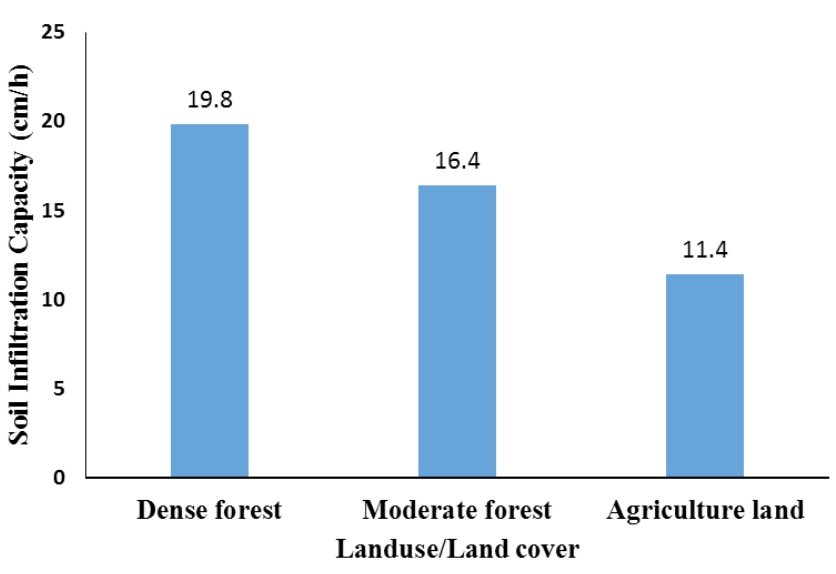

Figure 4: Mean soil infiltration capacity of different land uses.

\section{Effect of soil texture on soil erosion rates}

The results revealed that the mean sand content was highest in agriculture land followed by moderate forest. Dense forest land has the lowest sand contents. Different land use land cover (LULC) mean differences comparisons revealed that clay content under dense forest was significantly higher than the clay contents of the moderate forest and agriculture land (Table 3). An increase in the sand contents while decrease in the clay contents was observed due to conversion of dense forest to moderate forest and agriculture land which makes the soil more venerable to erosion. Thus the agriculture lands have more soil loss followed by moderate forest cover. The minimum soil loss was recorded from the dense forest cover.

Clay fraction loss is due to migration down the soil profile. Erosion transports the finer particles as a result of breakdown of soil due to Organic Carbon (OC) loss in cultivated agriculture soils. The findings of Ayoubi et al. (2011) and Celik et al., (2005) gives supporting evidence to these results.

Table 3: Soil texture of different land uses of Miandam Swat.

\begin{tabular}{lllll}
\hline Status & $\begin{array}{l}\text { Sand } \\
\text { (\%) }\end{array}$ & $\begin{array}{l}\text { Silt } \\
\text { (\%) }\end{array}$ & $\begin{array}{l}\text { (\%) } \\
\mathbf{( \% )}\end{array}$ & Soil class \\
\hline Dense forest & 56 & 24 & 20 & Sandy Clay Loam \\
Moderate forest & 62 & 21 & 17 & Sandy Clay Loam \\
Agricultural land & 64 & 20 & 16 & Sandy Loam \\
\hline
\end{tabular}

Effect of rainfall on soil erosion

Soil erosion increased significantly as the amount of rainfall increases (Figure 5). The susceptibility of the soil to erosion is indicated by the amount of soil loss from a small increment due to rainfall.

Agricultural lands have high intensity of erosion (4.6 $\left.\mathrm{mm} \cdot \mathrm{yr}^{-1}\right)$ due to mean annual rainfall of $31.46 \mathrm{~mm} \cdot \mathrm{yr}^{-1}$ followed by moderate forest cover having mean annual erosion of $2.9 \mathrm{~mm} \cdot \mathrm{yr}^{-1}$ due to mean annual rainfall of $31.46 \mathrm{~mm} \cdot \mathrm{yr}^{-1}$. The lowest soil erosion $\left(2.1 \mathrm{~mm}_{\mathrm{yr}} \mathrm{r}^{-1}\right)$ occurs at dense forest cover with mean annual rainfall of $31.46 \mathrm{~mm}^{-y^{-1}}$ (Table 4). According to different research findings, vegetation plays a vital role in improving the quality and quantity of water in the natural process of hydrological cycle. Vegetation acts as filter to purify and provide clean water from upstream watershed to downstream area. Raindrops detached the soil particles with their kinetic energy as it falls on the upper atmosphere on the surface of bare land. The rate of erosion decreases in the presence of vegetation because this force of movement is taken by its foliage and this process is called interception. The storage of water for effluent stream system increases due to fallen litters and leaves of vegetation

Table 4: Effect of rainfall on soil erosion under different land uses.

\begin{tabular}{|c|c|c|c|c|}
\hline \multirow{2}{*}{$\begin{array}{l}\text { Land use/ } \\
\text { Land cover }\end{array}$} & \multirow{2}{*}{$\begin{array}{l}\text { Mean annual erosion } \\
\left(\mathrm{mm} . \mathrm{yr}^{-1}\right)\end{array}$} & \multirow{2}{*}{$\begin{array}{l}\text { Mean annual rainfall } \\
\left(\mathrm{mm} . \mathrm{yr}^{-1}\right)\end{array}$} & \multicolumn{2}{|c|}{ Statistical analysis } \\
\hline & & & Over all P-Value & Status comparison \\
\hline Dense forest & 2.1 & 31.46 & 0.001 & DFMFAL $* * *$ \\
\hline Moderate forest & 2.9 & 31.46 & 0.001 & MFDFAL $* * *$ \\
\hline Agriculture land & 4.6 & 31.46 & 0.001 & ALDFMF $^{* * *}$ \\
\hline
\end{tabular}

December 2020 | Volume 39 | Issue 2 | Page 139 
and remained on the surface of the watershed which also lower the runoff velocity and encourage to increase the infiltration rate as well.

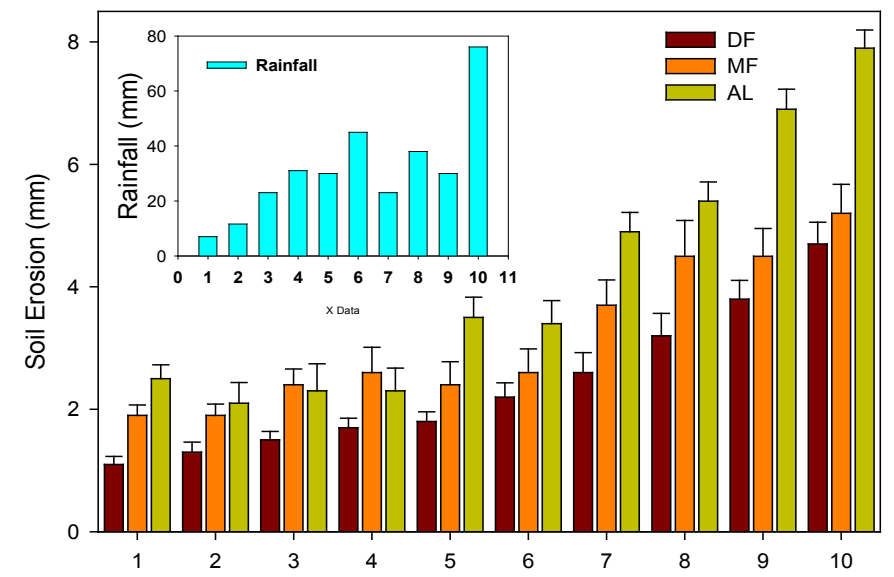

Figure 5: Effect of rainfall $(\mathrm{mm})$ on soil erosion.

\section{Conclusions and Recommendations}

The erosion rates of the dense and moderate forested areas differ significantly as compared to the agricultural area due to fact that both the dense and moderate forest contained trees and small plants. Further the addition of fallen leaves and litters helps in reducing the amount of soil erosion. Soil texture also play an important role in the soil stability. The soil of dense forest land with higher sand contents and lower clay contents is less susceptible to erosion followed by moderate forest land while the soil of agriculture land with lower sand contents and higher clay contents is more susceptible to erosion.

Due to higher infiltration capacity of the soil of dense forested areas, soil erosion is less followed by moderate forest. The soil of agriculture land have less infiltration capacity rates thus having more soil erosion. The soil infiltration rates are higher due to higher amount of rainfall which results in greater amount of runoff and transports the suspended sediment load in a much greater amount.

This is fundamental in areas largely dedicated to agriculture, including high-quality plantations (e.g., olive groves, vineyards), and urban tourist areas, which are also suffering a strong loss of free soil due to landuse change and urbanization in recent years.

\section{Novelty Statement}

This study quantifies real time soil loss at field level using on site erosion measurement through erosion pipes installation. For the very first time this technique was used in Northern areas of Pakistan for estimation of soil loss.

\section{Author's Contribution}

Nowsher Yousaf conducted on site erosion measurement, laboratory analysis, data analysis, manuscript draft; Bushra Khan supervised the research work, conducted field visits, provided laboratory analysis guidance and reviewed the manuscript; Dennis C. Flanagan supervised the study as foreign supervisor and provided critical review of the manuscript; Ishaq Ahmad Mian co-supervised the research project, conducted field visits and provided laboratory facility for the experiments and data analysis.

\section{Conflict of interest}

The authors have declared no conflict of interest.

\section{References}

Ayoubi, S., F. Khormali, K.L. Sahrawat, A.C., Rodrigues de Lima. 2011. Assessing impacts of land use change on soil quality indicators in a Loessial Soil in Golestan Province, Iran, J. Agr. Sci. Tech., 13,727-742.

Boix-Fayos, C., M. Martínez-Mena, C. ArnauRosalén, E.A. Castillo and V. Albaladejo. 2006. Measuring soil erosion by field plots: Understanding the sources of variation. Earth Sci. Rev., 78: 267-285. https://doi. org/10.1016/j.earscirev.2006.05.005

Celik, M.U, G. Sharma, A.M. Tekalp and E. Saber. 2005. Lossless generalized-LSB data embedding. IEEE Trans. Image Process.,14: 253-266.

Cerdà, A., 1999. Parent material and vegetation affect soil erosion in eastern Spain. Soil Sci. Soc. Am. J., 63: 362-368. https://doi.org/10.2136/ sssaj1999.03615995006300020014x

Cerdà, A., 2000. Aggregate stability against water forces under different climates on agriculture land and scrubland in southern Bolivia. Soil Tillage Res., 36: 1-8. https://doi.org/10.1016/ S0167-1987(00)00155-0

Cerdà, A., 2002. The effect of season and parent material on water erosion on highly eroded soils in eastern Spain. J. Arid Environ., 52: 319-337. https://doi.org/10.1006/jare.2002.1009

De Baets, S., D. Torri, J. Poesen and J. Meersmans. 
2008. Modelling increased soil cohesion due to roots with EUROSEM. Earth Surface Process Landfill, 33: 1948-1963. https://doi. org/10.1002/esp.1647

Ding, L., K.L. Chen, S.G. Cheng and X. Wang. 2015. Water ecological carrying capacity of urban lakes in the context of rapid urbanization: A case study of East Lake in Wuhan. Phys. Chem. Earth, Parts A/B/C, pp. 89-90, 104113. https://doi.org/10.1016/j.pce.2015.08.004

Gimenez-Morera, A., J. Sinoga and A. Cerda. 2010. The impact of cotton geotextiles on soil and water losses from Mediterranean rain-fed agricultural land. Land Degrad. Dev., 21: 210217. https://doi.org/10.1002/1dr.971

Haghiabi, A.H., J. Abedi-Koupai, M. Heidarpour and J. Mohammadzadeh-Habili. 2011. A new method for estimating the parameters of Kostiakov and modified Kostiakov infiltration equations. World Appl. Sci. J., 15(1): 129-135.

Hussain, S.K., 2005. World Wide Fund for Nature report on Payment for Environmental Services (PES) Miandam Swat Pakistan.

Idike, F.I., 2002. Experimental evaluation of infiltration equations for Nsukka soil. J. Agric. Eng. Technol., 10, 28-34.

Koehler, F.E., C.D. Moodie and B.L. McNeal. 1984. Laboratory manual for soil fertility. Washington State University, Pullman WA.

Kukal, S.S., H.S. Sur and S.S. Gill. 1991. Factors responsible for soil erosion hazard in sub montane Punjab, India. Soil Use Manag., 1: 3844. https://doi.org/10.1111/j.1475-2743.1991. tb00844.x

Le Roux, J.J., T.L. Morgenthal, J. Malherbe, D.J. Pretorius and P.D. Sumner. 2008. Water erosion prediction at a national scale for South Africa. Water South Africa, 34: 305-314. https://doi. org/10.4314/wsa.v34i3.180623

Le Roux, J.J., T.S. Newby and P.D. Sumner. 2007. Monitoring soil erosion in South Africa at a regional scale: review and recommendations. South Afr. J. Sci., 103: 329-335.

Lee, G.-S. and K.H. Lee. 2006. Scaling effect for estimating soil loss in the RUSLE model using remotely sensed geospatial data in Korea. Hydrol. Earth Syst. Sci. Dis., 3: 135-157. https://doi.org/10.5194/hessd-3-135-2006

Leh, M., S. Bajwa and I. Chaubey. 2011. Impact of land use change on erosion risk: An integrated remote sensing, geographic information system and modeling methodology. Land Degrad. Dev., 1: 1-13. https://doi.org/10.1002/1dr.1137
Leh, M., S. Bajwa and I. Chaubey. 2013. Impact of land use change on erosion risk: An integrated remote sensing, geographic information system and modeling methodology. Land Degrad. Dev., 24: 409-421.

Lieskovsky, J. and P. Kenderessy. 2012. Modelling the effect of vegetation cover and different tillage practices on soil erosion in vineyards: A case study in Vra'ble (Slovakia) using WATEM/SEDEM. Land Degrad. Dev., 25: 288-296. https://doi.org/10.1002/ldr.2162

Liu, Y., 2016. Landscape connectivity in soil erosion research: Concepts, implication, quantification. Geog. Res., 1: 195-202.

Ma, X., Y. He, J. Xu, M. van Noordwijk and X. Lu. 2014. Spatial and temporal variation in rainfall erosivity in a Himalayan watershed. Catena, 121: 248-259. https://doi.org/10.1016/j. catena.2014.05.017

Mandal, D. and V. Sharda. 2013. Appraisal of soil erosion risk in the eastern Himalayan region of India for soil conservation planning. Land Degrad. Dev., 24: 430-437.

Marques, M.J., R. Bienes, L. Jimenez and R. PerezRodriguez. 2007. Effect of vegetal cover on runoff and soil erosion under light intensity events. Rainfall simulation over USLE plots. Sci. Total Environ., 378: 161-165. https://doi. org/10.1016/j.scitotenv.2007.01.043

Meadows, M.E., 2003. Soil erosion in the Swart land, western Cape Province, South Africa: Implications of past and present policy practice. Environ. Sci. Policy, 6: 17-28. https://doi. org/10.1016/S1462-9011(02)00122-3

Mohammad, A.G. and M.A. Adam. 2010. The impact of vegetative cover type on runoff and soil erosion under different land uses. Catena, 81: 97-103. https://doi.org/10.1016/j. catena.2010.01.008

Montgomery, D.R., M.Y.F. Huang and A.Y.L. Huang. 2014. Regional soil erosion in response to land use and increased typhoon frequency and intensity, Taiwan. Quat. Res. (United States), 1: 15-20. https://doi.org/10.1016/j. yqres.2013.10.005

Nadeu,E.,A.A.Berhe,J.de Vente and C.Boix-Fayos. 2012. Erosion, deposition and replacement of soil organic carbon in Mediterranean catchments: A geomorphological, isotopic and land use change approach. Biogeosciences, 9: 1099-1111. https://doi.org/10.5194/bg-9$1099-2012$

Niu,X.Y.,etal.,2015.Effectoflanduseonsoilerosion 
and nutrients in Dianchi Lake Watershed, China. Pedosphere, 25: 103-111. https://doi. org/10.1016/S1002-0160(14)60080-1

Oyonarte, N.A., L. Mateos and M.J. Palomo. 2002. Infiltration variability in furrow irrigation. J. Irrig. Drain. Eng., 128(1): 2633. https://doi.org/10.1061/(ASCE)07339437(2002)128:1(26)

Panagos, P., P. Borrelli, J. Poesen, C. Ballabio, E. Lugato, K. Meusburger and C. Alewell. 2015. The new assessment of soil loss by water erosion in Europe. Environ. Sci. Policy, 54: 438-447. https://doi.org/10.1016/j.envsci.2015.08.012

Pimentel, D., and M. Burgess. 2013. Soil erosion threatens food production. Agriculture, 3: 443-463. https://doi.org/10.3390/ agriculture 3030443

Rohrmann, A., R. Heermance, P. Kapp and F. Cai. 2013. Wind as the primary driver of erosion in the Qaidam Basin, China. Earth Planet. Sci. Lett., 374: 1-10. https://doi.org/10.1016/j. eps1.2013.03.011

Schonbrodt-Stitt, S., A. Bosch, T. Behrens, H. Hartmann, X. Shi and T. Scholten. 2013. Approximation and spatial regionalization of rainfall erosivity based on sparse data in a mountainous catchment of the Yangtze River in Central China. Environ. Sci. Pollut. Res., 20: 6917-6933. https://doi.org/10.1007/s11356012-1441-8

Schwab, A., D. Fangmeir, I. Elliot and K. Frerert. 1995. Soils and water conservation engineering. New York, John Wiley and Sons Inc. (Chapter 12), 15-35.

Serrano-Muela, M.P., E. Nadal-Romero, N. LanaRenault, J.C. González-Hidalgo, J.I. LópezMoreno, S. Beguería, Y. Sanjuan and J.M. García-Ruiz.2013. An exceptional rainfall event in the central western pyrenees: spatial patterns in discharge and impact. Land Degrad. Dev., 10,1002/ldr.2221. https://doi.org/10.1002/ ldr. 2221

Shi, Z.H., N.F. Fang, F.Z. Wu, L. Wang, B.J. Yue and G.L. Wu. 2012. Soil erosion processes and sediment sorting associated with transport mechanisms on steep slopes. J. Hydrol., 454455, 123-130. https://doi.org/10.1016/j. jhydrol.2012.06.004

Singh, Y., 2001. Geo-ecology of the Trans Satluj Punjab-Haryana Siwalik Hills, NW India. ENVIS Bull. Himalayan Ecol., 9: 19-38.

Sreejani, T.P., D. Abhishek, G.V.R. Srinivasa Rao and Y. Abbulu. 2017. A study on infiltration characteristics of soils at Andhra University Campus, Visakhapatnam. Int. J. Environ. Res. Dev., 7(1): 29-44.

Sun, W., Q. Shao, J. Liu and J.Zhai. 2014. Assessing the effects of land use and topography on soil erosion on the Loess Plateau in China. Catena, 121: 151-163. https://doi.org/10.1016/j. catena.2014.05.009

Vásquez-Méndez, R., E. Ventura-Ramos, K. Oleschko, L. Hernández-Sandoval, J. Parrot, M.A. Nearing. 2010. Soil erosion and runoff in different vegetation patches from semiarid Central Mexico. Catena, 80: 162-169. https:// doi.org/10.1016/j.catena.2009.11.003

Vrieling, A., M.D.J. Steven, G. Sterk and S.C. Rodrigues. 2009. Timing of erosion and satellite data: A multiresolution approach to soil erosion risk mapping. Int. J. Appl. Earth Observ. Geoinf., 3: 267-281. https://doi.org/10.1016/j. jag.2007.10.009

Wei, W., L. Chen, B. Fu, Z. Huang, D. Wu and L. Gui. 2007. The effect of land uses and rainfall regimes on runoff and soil erosion in the semi-arid loess hilly area China. J. Hydrol., 335: 247-258. https://doi.org/10.1016/j. jhydrol.2006.11.016

Wu,J. and H.Xie. 2011. Research on characteristics of changes of lakes in Wuhan's main urban area. Procedia Eng., 21: 395-404. https://doi. org/10.1016/j.proeng.2011.11.2031

Zhao, G., X. Mu, Z. Wen, F. Wang and P. Gao. 2013. Soil erosion, conservation and ecoenvironment changes in the Loess Plateau of China. Land Degrad. Dev., 24: 499-510. https://doi.org/10.1002/1dr.2246

Zhao, Q. D. Li, M. Zhuo, T. Guo, Y. Liao and Z. Xie. 2014. Effects of rainfall intensity and slope gradient on erosion characteristics of the red soil slope. Stochastic Environ. Res. Risk Assess., 2: 609-621. https://doi.org/10.1007/s00477014-0896-1

Zheng, F., 2006. Effect of vegetation changes on soil erosion on the loess plateau. Pedosphere, 16: 420-427. https://doi.org/10.1016/S10020160(06)60071-4

Ziadat, F. and A. Taimeh. 2013. Effect of rainfall intensity, slope, landuse and antecedent soil moisture on soil erosion in an arid environment. Land Degrad. Dev., 24: 582-590. https://doi. org/10.1002/1dr.2239 